\title{
Educating Through Music
}

From an "Initiation into Classical Music" for Children to Confucian "SelfCultivation" for University Students

Zhe Ji

\section{OpenEdition}

\section{Journals}

Electronic version

URL: http://journals.openedition.org/chinaperspectives/4133

DOI: 10.4000/chinaperspectives.4133

ISSN: 1996-4617

\section{Publisher}

Centre d'étude français sur la Chine contemporaine

\section{Printed version}

Date of publication: 1 July 2008

Number of pages: 107-117

ISSN: 2070-3449

\section{Electronic reference}

Zhe Ji, «Educating Through Music », China Perspectives [Online], 2008/3 | 2008, Online since 01 July 2011, connection on 28 October 2019. URL : http://journals.openedition.org/chinaperspectives/4133 ; DOI : 10.4000/chinaperspectives. 4133 


\title{
Educating Through Music
}

\author{
From an "Initiation into Classical Music" for Children to Confucian \\ "Self-Cultivation" for University Students
}

Confucian discourse in contemporary China simultaneously permeates the intertwined fields of politics and education. The current Confucian revival associates the "sacred", power and knowledge whereas modernity is characterized by a differentiation between institutions and values. The paradoxical situation of Confucianism in modern society constitutes the background of the present article that explores the case of a private company involved in promoting classical Chinese music to children and "self-cultivation" to students. Its original conception of "education through music" paves the way for a new "ethical and aesthetic" teaching method that leaves aside the traditional associations of ethics with politics. By the same token, it opens the possibility for a non-political Confucianism to provide a relevant contribution in the field of education today.

\section{The kingly way and transformative education, benevolent words and benevolent sounds}

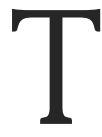
he Qing court's abolition in 1905 of the system of competitive civil service examinations, the curriculum for which was based largely on the Confucian Canon, marked the beginning of a modern but distinctly Chinese-style separation of politics and religion. ${ }^{(1)}$ This marked the disintegration of the traditional system in which Confucianism united politics, religion, and education under the control of an imperial regime, ${ }^{(2)}$ and the role of Confucian thought and the place it occupied in Chinese society underwent profound change. On the one hand, the abolition of the imperial examinations amounted to an official recognition that Confucianism was unable to provide an effective or adequate response to the massive political and social crises of the times; the building of a modern Chinese state could not be ideologically grounded in Confucian concepts of history and social theories, but had to turn to modern political theories and techniques of government originating in the West. On the other hand, the abolition of the examinations upset the dominant position that Confucianism had hitherto enjoyed in the field of education. The knowledge brought by the "new learning" (xinxue) and "practical learning" (shixue), as science and technologies were referred to, gradually replaced Confucian wisdom, which focused on the implementation of peaceful order through self-cultivation and on the transformation of the individual through education. More efficient in the exchange of political, economic, and social goods, these new forms of learning became the new "cultural capital."

Seen in this light, it was the removal of the link between Confucianism and the education and political systems that lay at the root of its decline, and of its present situation as a "wandering spirit." (3) This is the reason why attempts to position Confucianism in modern society have frequently developed in two directions: the restoration of a tradition of political legitimacy based on the notion of the "kingly Way"

1. Zhang Lun has appositely pointed out the links between the abolition of the examination system in China and the 1905 French law on the separation of church and state. The two events were not only simultaneous, they were also similar political responses to internal demands for modern "differentiation." See "1905 nian de yichan: xiandaixing, zhengjiao fenli yu yanlun ziyou (The legacy of 1905: modernity, secularity and freedom of expression)," Ershiyi shiji, no. 95, June 2006, pp. 103112.

2. See Gan Chunsong, Zhiduhua rujia jiqi jieti (Institutional Confucianism and its Dismantling), Beijing, Zhongguo renmin daxue chubanshe, 2003, pp. 220-243.

3. It is important to note that although in the process of China's modernisation Confucianism has lost the institutional guarantee of primacy in the political and educational domains, the relationship between Confucianism, politics, and education remains very complex. According to Gan Yang, for example, the state-building methods used by the Nationalist government and the Communist government both, to some extent, carried on the Confucian tradition, even if the latter denies it; see Gan Yang, "Ruxue yu xiandai: jianlun ruxue yu dangdai zhongguo (Confucianism and Modernity: on Confucianism and Contemporary China)," in Fudan daxue sixiangshi yanjiu zhongxin (ed), Jingxue, zhengzhi yu xiandai zhongguo (Classical studies, Politics and Modern China), Shanghai, Shanghai renmin chubanshe, 2007, pp. 5-23. On the de-Confucianisation of Chinese politics, see Yang Nianqun, "Ruxue zuowei chuantong zhongguo 'yishixingtai' hefaxing de lishi jiqi zhongjie (History of Confucianism as the Legitimate 'Ideology' of Traditional China and Its End)," in Zuori zhi wo yu jinri zhi wo: dangdai shixue de fansi yu chanshi (Yesterday's I and Today's I: Reflections and Interpretations on Contemporary Historical Science), Beijing, Beijing shifan daxue chubanshe, 2005, pp. 94-147. On the interactions between the construction of a modern educational space and the social, cultural and educational space of traditional China, see Wang Mingming "Jiaoyu kongjian de xiandaixing yu minjian gainian: min tai sancun chudeng jiaoyu de lishi guiji (The Modernity of the Educational Space and Popular Conceptions of It: Following the History of Elementary Teaching in Three Villages in Fujian and Taiwan)," in Shehuixue yanjiu (Sociology Studies), no. 6, 1999, pp. 6-10. 
(wangdao), and the re-establishment of a tradition of socialisation that focuses on "transformation through education" (jiaohua). ${ }^{(4)}$ These two tendencies are exemplified on the one hand by Xu Fuguan (1902-1982), who attempted to reconcile the Confucian theory of the primacy of the people with modern ideas about democracy, and on the other by Liang Shuming (1893-1988) and his social reform movement in the countryside. The past 20 years in post-Mao mainland China have seen efforts devoted to Confucian movements in both directions. We have witnessed the active promotion of a "political Confucianism" led by Jiang Qing and Kang Xiaoguang and, more recently, the emergence of a wide variety of extra-curricular activities in children's education, such as "reading the classics" (dujing) and the reintroduction of traditional culture (guoxue, literally "national studies") $)^{(5)}$

Of course, the involvement of contemporary Confucians in politics is inseparable from their activities in the field of education. A fundamental concept of Confucian political thought, be it traditional or modern, is the promotion through education of "virtuous government" (dezhi), and it is this integration of politics and education that has led many present-day liberal intellectuals to adopt a cautious attitude to the Confucian revival. Indeed, from the moment when "cultivation of the self" (xiushen) becomes a preparation for "ruling the state" (zhiguo), and even "bringing peace to the world" (ping tianxia), there is a strong risk that the Confucian moral principle of "not applying to others what you would not wish for yourself" (ji suo bu yu, wu shi yu ren) could be transformed into the oppressive imperative of "impose on others what you wish for yourself." This is a particularly problematic issue for contemporary Confucian movements that are attempting to reinstitute a secularised space in education. If "study" (хиe) with the aim of self-cultivation is unable to maintain its autonomy with regard to "skills" (shu) for ruling the State, research in and teaching of classical culture risk being reduced to the role of pawns in a game of realpolitik, a state of affairs that would be completely at odds with the original intention of reviving Chinese culture.

The overlapping of Confucian teaching with politics does, of course, have a historical origin, but is not unrelated to the manner in which present-day Confucians intervene in the field of education. What is called Confucian education today can largely be summed up as a discursive practice centred around the texts known as the Canon, which involves reading, memorising, explaining, and commenting on the "books of the sages and men of virtue" (shengxianshu). In fact, the contemporary revival of teaching about traditional Chinese culture began with the practice of "reading classical texts." In the mid-1990s, for example, the main focus of the first movements to promote the renewal of traditional Chinese culture, launched by Wang Caigui and Nai Huaijin, was "reading the classics" for children. The first organisation of university students for the promotion of classical culture, the Yidan school (Yidan xuetang), was set up in Beijing at the end of 2000 with the principal objective of organising and training student volunteers to take part in activities involving the "reading, reciting, and memorising" of classical texts in primary schools. The massive and controversial textbooks on traditional culture edited by Jiang Qing in 2004 are all entitled "texts for recitation." ${ }^{(6)}$

There is no doubt that reading and reciting aloud is an elementary method of transmitting written tradition, one that was characteristic of old-style education in China and that seems to be direct and effective. But that is precisely the problem. First of all, such reading and reciting cannot be done without "classical" texts. Yet the criteria that define a classic as such are never neutral. As far as Confucianism is concerned, the classics are for the most part texts endowed with a specific ethico-political significance, selected and endorsed by an authoritarian regime that amalgamated politics and education. The chosen content shows that an education in traditional culture centred on reading and recitation was to some extent simply a way of teaching topics and ethico-political principles presumed to be valid in perpetuity. Moreover, reading and recitation makes for an extremely limited method of learning, because of the emphasis on the

4. The modern reconstruction of Confucianism is not, of course, limited solely to these two spheres. The western concept of "religion" is a matter of equal importance to contemporary Confucians. On the influence of the western concept of "religion" on the religious landscape of China and on the relationship between politics and religion, see Vincent Goossaert, "L'invention des 'religions' en Chine moderne," in Anne Cheng (ed), La pensée en Chine aujourd'hui, Paris, Gallimard, 2007, pp. 185-213. On the interpretation and application of the western concept of "religion" among late imperial Confucians, see Hsi-Yuan Chen, Confucian Encounters with "Religion": Rejections, Appropriations, and Transformations, London, Routledge, 2006. On the recent debates in mainland China on the religious nature of Confucianism, see Han Xing, Rujiao wenti: zhengming yu fansi (The Problem of the Confucian Religion: Debates and Reflections), Xi'an, Shaanxi renmin chubanshe, 2004

5. On the rise of political Confucianism and the discourse related to it, see Ji Zhe "Confucius, les libéraux et le Parti. Le renouveau du confucianisme politique," La Vie des Idées, May 2005, pp. 9-20; Sébastien Billioud, "Confucianism, 'cultural tradition' and official discourses in China at the start of the new century," China Perspectives, no.3, 2007, pp.50-65. On the re-emergence of Confucianism in education and its political and social implications, see Sébastien Billioud and Joël Thoraval, "Jiaohua: The Confucian Revival in China as an Educative Project," China Perspectives, no.4, 2007, pp. 4-21; Ji Zhe, "Traditional Education in Contemporary China: Conservative and/or Liberal?", Chinese Cross Currents, nos. 2-3, 2005, pp. 32-41.

6. Jiang Qing (ed), Zhonghua wenhua jingdian jichu jiaoyu songben (Recitation Texts for Elementary Teaching of the Classics of Chinese Culture), Beijing, Gaodeng jiaoyu chubanshe, 2004. 
ability to repeat, memorise, and quote from existing and already conceptualised texts, rather than on the spirit of creativity, debate, and criticism. Such a conservative style of teaching and the teacher-pupil relationship it implies are, to the liberal spirit, simply the reflections of authoritarian political concepts in education.

Even from the point of view of the pedagogical method advocated and applied by Confucius himself, merely reading and reciting the classics is problematic. Because it is so difficult to express the central idea of Confucianism, ren (benevolence), in words, it is also difficult to comprehend it through words. The Analects include a dialogue between the Master and Sima Niu, one of his disciples: ${ }^{(7)}$

\section{Sima Niu asked about ren, and Confucius replied: \\ The ren man is hesitant to speak. \\ Sima Niu: So being hesitant to speak is what is meant by ren? \\ The Master: When it is not easy to act in accordance with ren, how could it be possible to speak of it?}

The philosopher Zhang Xianglong ${ }^{(8)}$ interprets this exchange as meaning that ren, or benevolence, is rooted in experience, in what a man has lived and felt in his life, whereas the teaching relating to it is often "disconnected from this experience and placed within clearly defined limits." Confucius' solution to this problem was to practise and teach his disciples the "six arts" (the rites, music, archery, chariot-driving, writing, and mathematics). His followers in later generations established their own "six arts": the Odes, the Documents, the Classic of Changes, the Rites, the Spring and Autumn Annals and the Classic of Music. According to Zhang, such an apprenticeship in the "arts" is "an activity that is at once flexible, adaptable, dynamic, joyous, and creative, and in which the subject and the object are united in a non-conceptualised and pre-reflexive way."

To put it simply, an education centred on the "arts" of which Confucius spoke cannot be restricted to "benevolent words" (renyan) that convey a set, normative knowledge, nor can it consist solely of disciplined training in such practices as reading and recitation. It is only through "recreation" (you), ${ }^{(9)}$ which is hedged by fewer norms, that the learner can experience ren in its multiple manifestations. Confucius said: "It is for want of a [political] function that I have had to become versed in many different arts." ${ }^{(10)}$ His words imply a certain opposition between politics and the arts. To what extent can the arts enable Confucianism today to put aside its classical political mantra of "benevolent words" and re-occupy the mainstream educational space? Any theory-based definitive statements on this question are bound to be crude. Here, our interest lies in a particular approach to the teaching of classical culture through music (yuejiao), a programme called "Initiation into Classical Music" (guoyue qimeng) that has been launched by Ms. Deyin and the Deyin Culture Society she founded in Xi'an. In this programme, re-invented "classical Chinese music" is seen as an educative medium that, though long forgotten, is as important, if not more so, than written texts; for "benevolent words do not affect men as profoundly as the benevolent sounds of music (rensheng), and good government wins the hearts of the people less easily than good education." (II) With the change of emphasis from "benevolent words" to "benevolent sounds," the traditional "ethico-political" axis of classical studies is to some extent transformed into an "ethico-aesthetic" axis. From this point of view, a return to tradition through music would appear more suitable for the establishment of an apolitical teaching method and "techniques of the self" than reading the classics with the idea that actions are always based on words.

\section{Music as sounds of virtue: The invention of music education classics}

As with all re-invention of tradition, an "Initiation into Classical Music" programme that aims to reconstruct education through music must begin by identifying the classical materials, believed to have been handed down from the past, on which teaching can be based. Although in Chinese history the tradition of music is as important as the tradition of ritual, if not more so, ${ }^{(12)}$ it lacks a clear and distinct continuity that can be easily perpetuated. The Classic of Music is the only one of the six Confucian classics to have been lost long ago. Only a few fragments relating to ancient music are preserved in the chapter on "Music" in the Book of Rites and in the passage "Grand Master of Music" in the chapter on "Celestial Functionaries" in the Rites of Zhou.

7. Lunyu - Yanyuan (Analects, chapter XII).

8. Zhang Xianglong, "Ren yu yi (Benevolence and Art)," in Zhao Tingyang (ed), Lunzheng (Tractatus) III, Nanning, Guangxi shifan daxue chubanshe, 2003, pp. 290-311.

9. See Lunyu - Shu'er (Analects, chapter VII ): "Confucius said: Concentrate your heart on the Way, base yourself on Virtue, model your actions on ren, and take your recreation in the arts."

10. Lunyu - Zihan (Analects, chapter IX).

11. Mengzi - Jinxin shang (Mencius, chapter VIIA).

12. Xu Fuguan, for example, believes that in the thought of Confucius the place of music is higher than that of the rites. See Zhongguo wenhua de jingshen (The Spirit of Chinese Culture), Shanghai, Huadong shifan daxue chubanshe, 2001, p. 3. 
of notation has been used in transcribing scores for the instrument. Instead of noting the pitch and duration of a note, it records the movements executed by the musician in specified positions on the instrument, through a collection of signs similar to Chinese characters. More than 150 of these ancient scores are still in existence today.

For all these reasons, the qin can justifiably claim to be an instrument that symbolises the continuity and uniqueness of Chinese culture. There is another reason why Deyin selected this instrument, however. According to her, the gin most perfectly embodies the spirit of music in Chinese culture. In the Book of Rites, the chapter on "Music" proposes a distinction between music (yue), modulated sounds (yin), and noises (sheng) in the following terms:

All modulated sound is produced in the minds of men; music communicates with the ethical order.

Hence, animals know noise, but not modulated sound, and the masses of the common people know modulated sound, but they do not know music. It is only the virtuous man (junzi) who can [really] know music.

In other words, noise, sound, and music can be placed in a hierarchy according to their moral quality. The capacity to produce noise (sheng) is something that is shared by men and animals alike, but only those noises that come from "the minds of men" can be considered as modulated sounds (yin), and only the modulated sounds of a virtuous man, who is fully cognisant of ethical requirements and therefore endowed with internal harmony, can be called music. That is why "the sounds of virtue (deyin) are what constitute music." (15)

Virtue is the manifestation of Nature; music is the blossoming of virtue. Metal, stone, silk, and bamboo are the instruments of music. Poetry gives expression to the aspirations, song exalts the voice, dance puts the body into action. All three must be rooted in the heart before the breath of music can accompany them. That is why the deeper the feelings, the clearer the expression, and the stronger the breath, the more effective the transformation. With internal harmony and fluidity, expressed externally by beauty and strength, it is in music alone that there cannot be any artifice. ${ }^{(16)}$

How then can the music of the gin embody the loftiest "sounds of virtue"? First of all, from the point of view of musical aesthetics, the timbre of the qin is pure and melodi- ous when high-pitched, deep and remote when low-pitched; it is always graceful and elegant, and conforms to the requirement for "harmony" ("The ultimate degree of music resides in harmony" $\left.{ }^{(17)}\right)$. The silk strings impart a soft quality to the sound, like the voice of a man speaking to himself, "never noisy when strong, never faint when subtle," and music and silence give rise to each other. In addition, the qin is usually played only in a private setting, among friends and connoisseurs, and such music conforms perfectly to the requirement for "stillness" ("Music comes from within and therefore it is still" $\left.{ }^{(18)}\right)$. Qin tunes are normally solos, simple compositions with a compact sound quality, and this corresponds to the requirement for "ease" ("Great music is distinguished by its ease" $\left.{ }^{(19)}\right)$. The harmony, stillness, and ease that are the peculiar aesthetic qualities of Chinese music are all echoes of the Confucian moral requirement for ren (benevolence).

From a sociological perspective, the music of the qin carries a good deal of cultural information relating to the Confucian concept of ethics, and thus can stimulate people's moral imagination and their sense of cultural identity. The literature reveals that Confucius himself played the qin, and strove to integrate music and the cultivation of ren in himself.

In 2003, the art of the gin was placed on the UNESCO register of Masterpieces of the Oral and Intangible Heritage of Humanity. Since then, the gin has been in vogue in China, and there has been a great increase in the number of people learning to play it. But in 2000, when Deyin began to put together all the material on the qin that she could find, very few people were interested in it - a total of about a thousand people played it, and it was extremely hard to find any good quality recordings. Nevertheless, Deyin continued researching and gathering material on the gin. She contacted well-known qin players, among them Gong $\mathrm{Y}_{i}$, Lin Youren, and Yao Gongbai, and visited them one by one, collecting and recording some beautiful ancient melodies. After two years of hard work, she finished making the recordings and putting together teaching materials. In April 2003, with the money she had saved over several years and loans from friends and relations, she set up the Deyin Culture Society in Xi'an, and founded the Deyin Culture Education Centre.

\footnotetext{
15. Hence the name adopted by the founder of the "Initiation into Classical Music" movement.

16. Liji - Yueji (Book of Rites, chapter on "Music").

17. Liji - Yueji.

18. Liji-Yueji.

19. Liji - Yueji. See Xu Fuguan, Zhongguo wenhua de jingshen, Chapter I, where Xu analy-
} ses music that moves from "stillness" to achieve the quality of ren. 
In January 2004, her Initiation into Classical Music was published. It comprised a set of $12 \mathrm{CDs}$, a Listening Guide and a Teachers' and Parents' Handbook. The first edition sold 5,000 copies; the second edition of 6,000 copies was produced in 2007, and is expected to meet demand over the next three to five years.

The Initiation into Classical Music is divided into three sections, according to the themes of the tunes and the moods associated with them: "Sages," "Human Beings," and "Seasons." There are 75 pieces in all, over a third of them for the qin, with the rest consisting of representative works for other instruments. With the exception of a few pieces that were considered inappropriate for a young audience (such as the furious Guangling Tune and the excessively gloomy Orchid), almost all of the most important pieces in the qin repertoire for which arrangements are currently available are found in this collection.

\section{Elegant music touches the heart: The development of introductory music education for children}

Like the movement to encourage children to read the Classics, the Initiation into Classical Music was initially designed for children in kindergartens and primary schools. Its pedagogic concepts and course materials were disseminated principally by non-government organisations such as the Dafang Education Centre for Guided Reading for Children in Chinese and Western Cultures in Wuhan, and the Shaonan Centre for the Promotion of the Teaching of Culture through Reading the Classics in Xiamen, which were active in kindergartens and primary schools and among families who had participated in the movement for reading the classics. In 2003, Deyin gave the first public presentation of her project to initiate children into classical music, a project that "concentrates on cultivating character and that contributes, along with the practice of poetry, reading, and ritual/courtesy," to the enlightenment of children, and described her educational concept of an comprehensive introduction for children to the study of classical culture. Her presentation was well received, and many popular organisations involved in the promotion of traditional culture subsequently made contact with her.

In April 2004, at the suggestion of some senior figures in the world of music, Deyin organised a symposium at the National Conservatory of China, and invited some 30 scholars and experts from important institutions such as the
Central Conservatory of Music, the National Conservatory of China, the Chinese Academy of Arts Musicology Institute, and Peking University to take part. The title of the conference was "Reconstructing Chinese music education and reviving the spirit of culture." Large numbers of students attended, as did journalists from specialist publications. The participants all acknowledged the value of the programme, and some of the experts were visibly moved. They believe that the teaching of music in China today has not only lost the status it once had, but also suffers from a short-term approach that looks for instant success and values technique over culture. The initiation into classical music proposed by Deyin breaks with the system of classification and the teaching formulas habitually employed in music education in that it goes straight to the Dao as its starting-point and, by returning to the spirit of traditional culture, allows music education to rediscover its true foundations.

Indeed, the music education proposed in the programme involves no teaching of musical technique at all, but rather a daily exposure to the nurturing influence of the arts. The children are not required to learn any performance skills, and the listening they do involves no special techniques. The pedagogy starts from the assumption that music is the voice of the heart of the virtuous man, and that a deep understanding achieved in listening to it will be enough to awaken a spiritual resonance predisposed to the good and the beautiful. In ancient times it was said that "Music is rooted in the nature and emotions [of man], it permeates the skin and the flesh and stays concealed in the bone-marrow," (20) and thus it is natural that with time "elegant and touching songs will find an echo in [moral] rectitude." ${ }^{(21)}$ This process, which "shapes the natural disposition, cultivates the character, and awakens the intelligence" by "constantly influencing what is seen and heard, silently effecting transformation, imperceptibly and unconsciously bringing about change," can be summed up in the phrase "it is through elegant, touching music, [that] the nature of man will return to uprightness." (22)

To implement the educational principle of a "soundless transformation," one of the basic strategies of music educa-

20. Ban Gu (Han), Hanshu - Li yue zhi (Annals of the Han, "The Books of Rites and Music").

21. Liu Xiang (Han), Shuoyuan - Xiuwen (Garden of Sayings, "The Practice of Culture").

22. Zhou Lufeng (Qing) (ed), from scores passed down by Xu Qi, Wuzhizhai qinpu - Shanggu qinlun (Scores from the Wuzhi Studio, "Ancient Theories of the Qin"). 
tion has been the use of background music to create a mood, and Deyin suggests several ways of selecting background music. ${ }^{(23)}$ Collections of bright and cheerful tunes such as Songs on a spring morning, Lotus emerging from the water, and Fisherman's song can be used to rouse people in the mornings, or for daily activities such as games or recreation, while collections such as Walking beneath the moon on an autumn evening or Flowing waters, which are more suited to a calm environment, are good for resting or for lullabies. The lofty Rhapsody on an immortal or the tremendous Rivers and clouds of Xiaoxiang, or the tragic and lonely Moon over Guan Mountain, are not suitable as background music, and need to be listened to and appreciated simply for themselves. The principle underlying the appreciation classes sees music as "sharing artistic unity with poems, books, and ritual." Of course, such a unity no longer has any real links with the ancient unity of ritual and music in the aristocratic politics of the past, but it offers a way of using music to provide children with a comprehensive initiation into the arts that associates fine art, literature, and dance, so as to cultivate in them an affinity with and a sensitivity to traditional culture. For example, the Initiation into Classical Music recommends that while children are listening to a performance of the exciting tale of King Wen's Music, a classic Confucian tune, they should learn to recognise pictures of Confucius or King Wen, or read the poems about King Wen in the Book of Odes. ${ }^{(24)}$

Although it does provide sample lesson plans for appreciation classes, the Initiation into Classical Music insists on the importance of never explaining too much to children, and recommends that no demands should be placed on them with regard to music or the history relating to it. The principle behind this kind of music education is that on the one hand, children must listen to classical music, even the oldest and most "difficult," whether or not they understand it, but on the other hand it is necessary to maintain a balance between being too directive and too lax, so that free appreciation of the music is combined with progressive assimilation of cultural knowledge. To help people understand this idea, since 2004 Deyin has given numerous talks in kindergartens and primary schools in X'an, Beijing, Shanghai, Wuhan, and some places in Zhejiang and in Inner Mongolia, and has run many courses to train teachers, volunteers, and parents of children involved in music education. In August 2006, during the summer holidays, the Deyin Centre collaborated with the Confucius Institute at Renmin University to run a four-day advanced training course in Beijing for "key teachers and volunteers on the Initiation into
Classical Music and Culture Programme." The intensive course had input from specialists in philosophy, history, music, dance, and traditional medicine. In July 2007, the Deyin Centre and the Institute ran a second such course, and between them the two courses were attended by more than 200 people. Several dozen kindergartens and primary schools across China are currently using Deyin's teaching materials and methods to introduce their pupils to classical music.

In addition, Deyin managed to have her programme included in China's tenth official Five-Year Plan (2001-2005) for educational sciences, under the direction of the Office of the National Leadership Group for Educational Sciences Planning. This means that it was listed as one of the national projects set up for "Transmission of the National Culture and Research on Arts Education in Schools," and although this has not brought any government funding, it confers official recognition on the programme.

This legitimation by the government encouraged more teachers, and ten kindergartens and schools ${ }^{(25)}$ joined the programme, offering introduction to music in one- to three-year courses. Deyin asked these schools to try to create a "comprehensive classical studies atmosphere in the school" in line with the recommendations in the Initiation into Classical Music handbook, which involves making improvements to the auditory, visual, and spiritual "environments." In each school, one person was tasked with keeping a daily record of all the background music played. Deyin was responsible for providing the teachers with basic training in classical culture and music, which covered experimental work in reading and interpreting the classics, improvisation in poetry, dance, and music, and practical exercises in developing a feeling for music in general. The key principles of the project were variety and flexibility, and schools were encouraged to create their own teaching programmes in line with their particular circumstances and the different characteristics of the age groups in their charge. Regular evaluations were carried out and the results were recorded.

The aim of music education being to protect "the natural emotional and spiritual growth" of the children, teaching is focused on listening and appreciation - nothing more complex is required of the children, and the method does not

23. Deyin, Zoujin deyin yayue: Guoyue qimeng jiaoshi jiazhang bidu (Entering into sounds of virtue and music of elegance: Teachers' and parents' guide to Initiation in to Classical Music), Xi'an, 2004, pp. 11-13.

24. Ibid., pp. 29-32.

25. Two in Ningbo, two in Xi'an, three in Beijing, two in Shanghai and one in Xilinhaote, Inner Mongolia. 

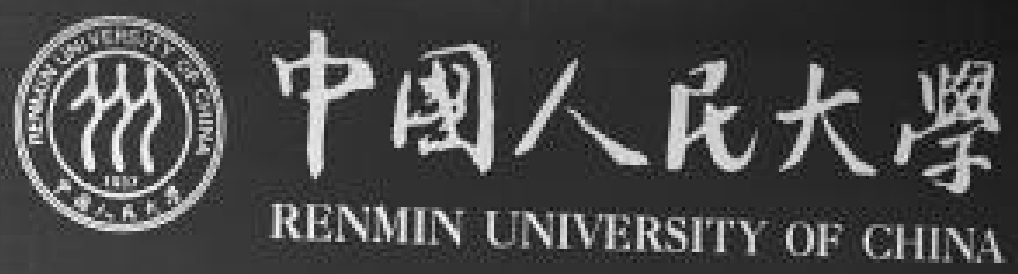

"Masters of Classical Music Tour" Concert and conference at Renmin University, Beijing, 2006 () Deyin

mer vacation experience in social service" by helping to introduce traditional culture and distribute information about it.

From 2005 onwards, with the help of academics and other supporters of the teaching of classical culture, Deyin's ideas on music education gradually spread to universities outside Xi'an, among them China Communications University and the University of Traditional Chinese Medicine in Beijing. In October 2006, Deyin launched a "Masters of Classical Music University Tour," starting in Beijing. She arranged for famous musicians from Shanghai and Guangdong, players of the gin, the $d i$, and the pipa, as well as some experts on classical dance, to give a series of concert-lectures in a number of universities. In 2007, the tour was repeated in other institutions and has been much in demand ever since.

In November 2002, a Confucius Institute was established at Renmin University in Beijing. Each year since 2004, around September 28 (Confucius' birthday), the Institute has organised a number of events to promote traditional Chinese culture during a "Confucian Culture Month." In 2006, the "Masters of Classical Music Tour" was one of the events that took place during this month. In 2007, the fourth such month was organised around music education, the main theme being "the promotion of education through music, to make people knowledgeable and generous-spirited (guangbo yiliang)." (26) Six of the eight lectures in the programme were given by musicologists and artists invited by Deyin, or by Deyin herself, and the closing ceremony included a concert of classical Chinese music. At the end of 2007, the Deyin Centre and the Confucius Institute signed a long-term cooperative agreement that included joint organisation of the annual Culture Month and the continuation of the summer courses for teachers of classical culture.

In 2004, while training student volunteers at Northwest Polytechnic University, Deyin put forward the idea of a course of classical studies for university students that would include training in classical music, Confucian and Daoist ideas, and traditional medicine. A lack of competent trainers, however, prevented the project from moving forward.

26. "Knowledgeable and generous-spirited" is a phrase from the Liji - Jingije (Book of Rites, "Presentations of the Canon"), where Confucius says "When visiting a country, one can tell what has been taught there. In the way of being of the people, [if one observes] that they are mild and gentle, they have been taught from the Odes; [if they demonstrate] erudition and intelligence, they have been taught from the Documents; if they are knowledgeable and generous-spirited, this bears witness to education through the Classic of Music; [if they show] integrity and perspicacity, they have been taught from the Classic of Changes; if they are respectful and frugal, from the Rites; [if they show] eloquence and imagination, from the Spring and Autumn Annals. Hence, the risk [inherent in the study] of the Odes is brutishness; that of the Documents, digression; that of Music, extravagance; that of the Classic of Changes, wiliness; that of the Rites, overcomplexity; and that of the Annals, disorder." 
More recently, she proposed a "traditional culture studies project" allied with a "call for the cultivation of the self," the aim of which is to encourage students to study, apply, and promote traditional culture. To this end, Deyin and her team trained activists, organised public lectures, and provided material for student associations. At the request of certain universities, these activities have been incorporated into "social practice" or "liberal education" programmes within the framework of university education. The costs are borne by the university, and Deyin's team has operated in an unofficial capacity. From 2008, however, this cooperation is being institutionalised, and the Deyin Centre has now signed an agreement to cooperate with the China Charity Federation (CCF). A new organisation for teaching classical culture, the Federation's "Education Centre for the Initiation into Classical Culture," has now been set up in Beijing. This centre will use donations for schools wanting to start teaching classical culture to finance gifts of books, invite lecturers, organise events, and support the setting up of student associations. To date, several dozen universities across China have contacted Deyin. Her plan is to focus on normal universities and some other key universities, and within five years to have more than a hundred universities and colleges running her programme of classical culture studies and selfcultivation for students.

\section{Perfecting the self through music?}

Deyin describes the kind of comprehensive education in classical culture that she is promoting, spearheaded by her "music education," as "a modern initiation into classical culture." In her view, the word "modern" here refers to four aspects of such education. Firstly, classical culture was originally transmitted very effectively through many different channels, and there was no need for a special process of initiation. But today, the current crisis of "dislocation" requires a different way of thinking about "returning to the source." Secondly, the study of classical culture, and of music in particular, originally consisted of an education of great depth that was restricted to the uppermost echelons of society, whereas the music education of today is more broad-based and intended for the masses. Thirdly, every era has a different mindset, so the content and method of the teaching of classical culture should be adapted to the needs of modern man. Fourthly, in a world that is always changing, the eternal values on which an education in classical culture is based should also be oriented towards the future.
Deyin's thinking bears many similarities to the ideas espoused by the movement for the renewal of traditional culture (for example, reading the Confucian classics), but appears to be more flexible and open. Indeed, this writer considers Deyin's approach to touch on questions that lie at the heart of the limits and possibilities of Confucian tradition in modern society.

Sociologically speaking, modern society is marked by "differentiation," which exists both as institutional differentiation, linked to the division of labour, and also as a pluralisation of values produced by secularisation. This dual process of differentiation originated in historical contexts specific to the economy and culture of the West, but has become one of the fundamental characteristics of modernity. It takes the form of universal exigencies for "efficiency" and "liberty." To some extent, the disintegration of institutional Confucianism in the twentieth century was the inevitable result of the expansion of modernity, the price China had to pay to become a modern state.

Today, differentiation has become a reality, and is also the departure point when we reflect on social phenomena; thus the status of Confucianism, which historically could not be properly classified by our modern categories as political, religious, or philosophical, remains ambiguous. Any attempt to re-establish a Confucianism that unites elements of politics, religion, and knowledge/education is bound to put liberal intellectuals on their guard and provoke their criticism. A Confucian religion poses no problem in principle, but if it intrudes into politics and becomes a state religion, that is a radically different matter. The classical culture is worth handing on to later generations, but as soon as it is starts to be treated as sacred and canonical knowledge, it is in danger of turning into obscurantism. At the end of the imperial era, the abolition of the traditional examination system and the encouragement of "practical learning" were intended to improve efficiency and thereby enable China to achieve a modernity characterised by institutional differentiation and the specialisation of activity and knowledge; the voices that speak out today against the renewal of Confucianism, warning of its potential to interfere in many different spheres (politics, religion, education, and knowledge), and of its desire ultimately to control values, do so in the name of the second characteristic of modernity, that is, in defence of liberty. However, modernity always develops in a paradoxical manner. Not only are there inherent tensions within efficiency and liberty themselves, but the differentiation of institutions (extreme specialisation) and values (pluralisation, and thence the problem of relativism) also puts the moral struc- 
tures of modern man in danger of becoming fragmented or superficial. It is as a direct response to this moral impasse that the initiation into classical music proposed by Deyin may be able to find a new route to reconstructing classical culture. The learning of classical culture that she envisages will remain at a prudent distance from technical transmission, academic research, and the demands of politics, and will seek to cultivate man's aesthetic capacity so that education can revert to "rousing to consciousness" (zhi liangzhi). Its principal methods consist not of inculcating a set of maxims and instructions, but of guiding the student, through an aesthetic experience, into understanding the spirit of a particular culture and a particular vision of the Cosmos. In this way, a "liberal education" in classical culture, facilitated by music, will be able to substitute a spiritual "harmony" $\left(h e^{*}\right)^{(27)}$ for the institutional "unity" (he $e^{* *}$ typical of the ancient Confucian order, thus reconciling tradition and modernity as satisfactorily as possible. To be sure, the ideal that inspires Deyin's vision of music education is still the shaping of a "virtuous man" who is the embodiment of classical culture, but served by a "liberal" education this kind of virtuous man will no longer be an individual whose thinking is modelled on particular discourses or ideas, or who mobilises symbolic and ritual resources in order to seize power. $\mathrm{He}$ will be a man who, situated between heaven and earth, past and present, "takes his recreation in the arts" (you yu yi) and "is perfected through music" (cheng yu yue). ${ }^{(28)} \bullet$

\section{- Translated by Caroline Mason}

$\begin{array}{ll}\text { Glossary } & \\ \text { cheng yu yue } & \text { 成于樂 } \\ \text { Deyin } & \text { 德音 } \\ \text { dezhi } & \text { 德治 } \\ \text { dujing } & \text { 讀經 } \\ \text { Gong Yi } & \text { 站一 } \\ \text { guangbo yiliang } & \text { 廣博易良 } \\ \text { gudian yinyue } & \text { 古典音樂 } \\ \text { guoxue } & \text { 國學 } \\ \text { guoyue qimeng } & \text { 國樂啟蒙 } \\ \text { guqin } & \text { 古琴 } \\ \text { he* } & \text { 和 } \\ \text { he** } & \text { 合 } \\ \text { ji suo bu yu, wu shi yu ren } & \text { 己所不欲, 勿施于人 } \\ \text { Jiang Qing } & \text { 蔣慶 } \\ \text { jiaohua } & \text { 教化 } \\ \text { junzi } & \text { 君子 } \\ \text { Kang Xiaoguang } & \text { 康曉光 } \\ \text { le } & \text { 樂 }\end{array}$

$\begin{array}{ll}\text { Liang Shuming } & \text { 梁漱溟 } \\ \text { Lin Youren } & \text { 林友仁 } \\ \text { Luo Yifeng } & \text { 羅藝峰 } \\ \text { minzu yinyue } & \text { 族音樂 } \\ \text { Nai Huaijin } & \text { 南懷瑾 } \\ \text { ping tianxia } & \text { 平下下 } \\ \text { pipa } & \text { 琵琶 } \\ \text { qin } & \text { 琴 } \\ \text { ren } & \text { 仁 } \\ \text { rensheng } & \text { 仁聲 } \\ \text { renyan } & \text { 仁言 } \\ \text { se } & \text { 瑟 } \\ \text { sheng } & \text { 馨 } \\ \text { shengxianshu } & \text { 圣賢書 } \\ \text { shi } & \text { 士 } \\ \text { shixue } & \text { 實學 } \\ \text { shu } & \text { 術 } \\ \text { Sima Niu } & \text { 司馬牛 } \\ \text { Wang Caigui } & \text { 王財貴 } \\ \text { wangdao } & \text { 王道 } \\ \text { xinxue } & \text { 新學 } \\ \text { xiushen } & \text { 修身 } \\ \text { Xu Fuguan } & \text { 徐復觀 } \\ \text { xue } & \text { 學 } \\ \text { Yao Gongbai } & \text { 姚公白 } \\ \text { Yidan xuetang } & \text { 一耽學堂 } \\ \text { you yu yi } & \text { 遊于藝 } \\ \text { you } & \text { 遊 } \\ \text { yue } & \text { 樂 } \\ \text { yuejiao } & \text { 樂教 } \\ \text { Zhang Xianglong } & \text { 張祥龍 } \\ \text { zhi liangzhi } & \text { 致良知 } \\ \text { zhiguo } & \text { 治國 } \\ & \\ & \end{array}$

27. See Liji - Yueji: "Music harmonises," and "Music is the harmony between Heaven and Earth." The harmonising effect comes not from accepting and respecting external norms but from resonance and sublimation of the "emotions." This is why "Music springs from the minds of men. The emotions are moved within, and are manifested in sounds. When these sounds combine to form a pattern, they are called music"; "Music (yue) is pleasure (le), that which men cannot stop themselves from feeling"; "The virtuous man returns to his emotions in order to find there harmony with his deepest aspirations."

28. See Lunyu - Taibo (Analects, chapter VIII): "Confucius said: A man is stimulated by the Odes, takes his stand on the rites, and is perfected by music." On the ontological significance of music and its Confucian interpretation, see Chen Yun, "Yinyue, shijian yu ren de cunzai: dui rujia 'cheng yu yue' de xiandai lijie (Music, Time and the Existence of Man: A Modern Understanding of the Confucian Idea of 'Perfecting Oneself through Music')," Xiandai zhexue (Modern Philosophy), no. 2, 2002, pp. 92-97. 